\title{
Learning to Teach through Writing with Students
}

\author{
CHEU-JEY LEE \\ Indiana University-Purdue University Fort Wayne
}

\begin{abstract}
This article presents a study of how dialogical notes can be used to inform teaching. A total of 43 pre-service teachers were asked to write dialogical notes back and forth with their students for one semester during their practicum in the elementary school. Their notes and reflections were analyzed to see what the pre-service teachers learned about their students through note writing. In addition, the impact of note writing on the pre-service teachers' teaching was also investigated. This article argues that dialogical notes serve as a viable tool for teachers to know students on a deeper level as well as to plan and adapt their teaching accordingly.
\end{abstract}

\section{Introduction}

In an era of mandate movements in the education world, curricula are often created topdown. For example, academic standards dictate what teachers are supposed to teach, which, in turn, decides what students learn in school. The top-down approach implies that the mandating agencies or teachers know better than students about what should be learned. This is in contrast to one of the most important tenets in education - building curricula on what students know or are interested in/concerned about. Harste (2008) recalled a story told by Arthur Combs in a keynote address at the annual meeting of the American Educational Research Association about how teachers usually see themselves, instead of their students, as foremost and central:

[H]e [Arthur Combs] was hired by the University of Florida to create a demonstration school. He said they had unlimited resources. Importantly, he got to select what teachers he wanted. Then not only did they design the school, but they also selected what furniture they wanted - tables instead of desks, walls that doubled as bulletin boards and whiteboards rather than wasted space. Instead of mandated textbooks they were able to select the instructional materials they wanted. They even, he reported, had the whole summer, on full salary, to plan the curriculum. 'The problem,' he said, 'is we opened in the fall and they sent us the wrong damn children.' (p. 36)

Though sarcastic, Combs' story brings to the fore the importance of knowing our students, which is often ignored. We as teachers often build our curriculum on what we remember about literacy instruction from our personal educational experiences. Harste (2008) argues, "One of the errors [he has] seen way too often is that teachers plan a child's instructional programs based on what they think they know about language and language learning without first finding out what the child already knows and understands" (p. 36).

Therefore, good teaching begins with knowing our students. In fact, literature on the importance of knowing students' prior knowledge on which to build curricula is not new to educators. For example, according to Dewey (2013), there are two sides to the educational process, and of the two sides, the psychological is the basis. He further proposes: 
Education, therefore, must begin with a psychological insight into the child's capacities, interests, and habits. It must be controlled at every point by reference to these same considerations. These powers, interests, and habits must be continually interpreted - we must know what they mean. They must be translated into terms of their social equivalents - into terms of what they are capable of in the way of social service. (Dewey, 2013, p. 34)

Similarly, in line with Moll (1992a, 1992b), Conley (2008) argues that students bring to our classroom "funds of knowledge," i.e., prior knowledge, that can be incorporated into our instruction. "Unfortunately," Conley (2008) continues, "these assets are often hidden, ignored by teachers, or - worse - treated as deficits" (p. 41). Lewison, Leland, and Harste (2008) suggest:

[A]ll students are capable and bring a wide range of experiential, cultural, and linguistic resources to the classroom, [and] our job as teachers is to figure out ways to regularly use these resources and to give them a place of prominence in what counts in our classrooms. (p. 28)

The question is: how can we know the students better to inform our teaching? As a literacy/language arts teacher educator, I was interested in this question and wanted to know how it applied to the context of my own teaching. Specifically, I was curious about how one of my class assignments, i.e., the dialogical notes ${ }^{1}$ assignment where pre-service teachers wrote dialogical notes with their elementary students, helped the pre-service teachers know and teach their elementary students. To turn this curiosity into an inquiry, I came up with two specific research questions as follows:

1. What did the pre-service teachers know about their students through the dialogical notes?

2. How did the pre-service teachers use the information they learned from the dialogical notes to inform their teaching?

With these two research questions in mind, I conducted a study based on the dialogical notes and reflections the pre-service teachers and their students completed. In what follows, I will present the findings of this study in detail. First of all, the context of the study, including the participants, will be described. This is followed by a discussion of the definition and theoretical basis of the dialogical notes. Then the themes that emerged from the analysis of the dialogical notes and reflections are presented to show what the pre-service teachers learned about their students from the notes (to address the first research question). Finally, the impact of note writing on the pre-service teachers' teaching is examined (to address the second research question).

\section{Context}

I teach in the teacher education program at a Midwestern university in the U.S. The university is located in a city where there are an increasing number of immigrant students. The student population is very diverse in one of the city's school districts with which I work closely in placing the pre-service teachers for their practicum. All schools in this school district include at least four racial/ethnic groups while most schools contain five or six. Yet most of the pre-service teachers in the teacher education program at my university are middle-class Caucasian and have little experience working with minority students. Most of them grew up and went to school with 
peers like themselves. Therefore, the practicum provides a great opportunity for them to interact with students from diverse backgrounds.

A total of 43 pre-service teachers participated in this study in the spring 2016. There were 37 females and six males. Among them, two were African American and two were Hispanic. The rest of the participants were White. They were in the first of a series of three literacy methods courses required for the elementary teacher education program. The pre-service teachers taking my course were primarily in their junior year, and there was a practicum requirement (at least 30 hours) attached to the course. I was responsible for teaching the course as well as supervising their practicum.

Each pre-service teacher was assigned to work one-on-one with an elementary student during his/her practicum and required to write notes with the elementary student dialogically. The purpose of this assignment was to help the pre-service teachers understand their student as well as motivate their student to form the habit of, and enjoy, writing. This assignment was also tied closely to the lesson plan assignment the pre-service teachers had to complete at the end of the semester. Specifically, the pre-service teachers were required to create a lesson plan based on what they had learned about their student from the dialogical notes. In addition, the pre-service teachers had to connect their lesson plan to at least two class readings/articles.

The pre-service teachers were asked to introduce themselves to their student in the first note and invite their student to respond to their note. The back-and-forth note writing took place for the entire semester. The pre-service teachers wrote notes with their student while they were in the classroom or asked their student to do it at home, depending on how much scaffolding their student needed or whether there were other assignments on which they had to work in the classroom. At the end, the pre-service teachers should complete at least five notes and have at least five notes written by their student. In addition, each pre-service teacher and his/her student were asked to write a reflection, i.e., what they learned from this writing experience.

\section{Previous Study and Theoretical Basis}

The dialogical notes assignment was created based theoretically on my previous study (Lee \& Lee, 2015) where notes were written in a home setting for approximately one year between me as the researcher and my daughter, Penn, as the co-researcher/participant. The written notes began with the topic on the St. Patrick's Day leprechaun. Penn learned about St. Patrick's Day in school. After that, she was very interested in the St. Patrick's Day leprechaun, an Irish fairy dressed in head-to-toe green, spending his time either making shoes or searching for gold (Kidzworld, 2014). One day, Penn drew a picture of a leprechaun and a picture of herself on one side of a card she made. She wrote on this side, "For the leprechaun" and "From Cheu-Jeys dolter [daughter] Penn" (to authentically present Penn's perspective, her writing is not corrected for grammatical/spelling errors throughout this article). Above her picture, she added a few words: "a pictuir of me." It appeared as if Penn thought she was only a child and had to introduce herself as "Cheu-Jeys dolter." On the other side of the card, she wrote:

Dear leprechaun

I love you and this pictuir I colord for you is for you and I always wanted to see how leprechauns look like. do you like green I bat you do and you like gold I know that. I love you leprechaun remember my name Penn.

Your Friend

Penn 
She placed her card along with a few toy gold coins (as a gift for the leprechaun) on the floor close to the couch. She said that the leprechaun might come at night and write her back.

While Penn was sleeping, I read her card and felt compelled to respond to her - and I did. I wrote her back and signed my name as "Leprechaun." She was so excited to see the response the next morning and wrote another note to the "Leprechaun." After a week of back-and-forth writing, I told her honestly that I had written all the notes in the name of "Leprechaun" and apologized to her. She was disappointed and stopped writing to me for a few days, but forgave me at last. Hence, we continued writing to each other except that I changed my pen name from "Leprechaun" to "Leprechaun Dad." We discussed many topics in our notes and wrote almost every day. We enjoyed the back-and-forth written conversations for approximately one year.

In line with Gee's (1990) sociolinguistic theory, I (Lee \& Lee, 2015) argued in my previous study that writing should be not only taught as an academic skill in school, but also acquired as a social practice situated within, and informed by, multiple Discourses, such as home, work, and church Discourses, which consist of all the beliefs, values, actions, etc. socially accepted in a sociocultural group and acquired through socialization. Following Heath (1983) and Street (1984, 1993, 1995), Gee (1990) advocates for a new formulation of literacy, in place of the traditional conception of literacy as the ability to read and write outside a social context, that "stresses the sorts of social practices in which reading, writing, and talking are embedded and out of which they develop, rather than the private cognitive 'skills' of individuals" (p. 49). Gee uses a "biker bar" example to illustrate that to be considered literate in the biker bar, we have to know what to say, how to say it, and what we are and do while we say it. Specifically, we need to play the "role" of a biker that is socially acceptable to other bikers in the bar. Gee (1990) calls such integral combinations of "sayings-doings-thinkings-feelings-valuings "Discourse," (p. xv) which he elaborates on as follows:

A Discourse is a socially accepted association among ways of using language, of thinking, feeling, believing, valuing, and of acting that can be used to identify oneself as a member of a socially meaningful group or "social network," or to signal (that one is playing) a socially meaningful 'role.' (Gee, 1990, p. 143)

Gee (1990) goes on to argue that "only within the context of the notion of Discourse that we can achieve a viable definition of 'literacy'..." (p. 150). A Discourse is used as the standard to distinguish insiders who are considered literate in a group from outsiders who are considered illiterate in that group. For example, to be considered literate in a biker bar, we need to say something like "Gotta match?" instead of "May I have a match for my cigarette, please?" even though the latter is grammatically perfect (Gee, 1990, p. xv). This is why literacy is meaningful only within a social context, i.e., a Discourse. Hence, being literate is being fluent in a Discourse.

Similarly, writing as a form of literacy should be regarded not merely as an academic skill to master, but also as a social practice. In this sense, writing reflects our lived experiences. It is concerned with what we do, what we see, what we believe, how we feel, etc. In other words, writing provides an avenue through which we can understand, and be understood by, other people. In an educational context, educators can better understand their students through writing with them. Therefore, building on my previous study where notes were written dialogically between me and my daughter as a form of literacy situated in a social context, the dialogical notes assignment was created as one of the class requirements for the pre-service teachers to complete with their 
elementary students during the practicum. The assignment served as a tool for the pre-service teachers to communicate dialogically and socially with their elementary students at a deeper level.

\section{Analysis of Dialogical Notes and Reflections}

The purpose of analyzing the dialogical notes and reflections is to answer the first research question put forth at the beginning of this article: what did the pre-service teachers know about their students through the dialogical notes? In addition, the analysis is also closely related to the second research question: how did the pre-service teachers use the information they learned from the dialogical notes to inform their teaching? In this section, I will focus on addressing the first research question and present the themes/patterns that emerged from the dialogical notes and reflections about what the pre-service teachers had learned about their students.

Again, a total of 43 pre-service teachers participated in this study. Therefore, there were 43 sets of dialogical notes completed by the pre-service teachers and the elementary students with whom they worked. In addition, each pre-service teacher and elementary student also wrote a reflection on this writing experience. Instead of imposing an a priori set of theoretical categories on the data, the notes and reflections were coded and analyzed to see whether or not certain themes or patterns emerged through the hermeneutic reconstructive analysis, which "reconstructs, into explicit discourse, cultural and subjective factors that are largely tacit in nature" (Carspecken, 1996, p. 93). The analytical coding process focuses on the internal connection between meanings instead of the external correlation between variables. Carspecken (1996) explains the hermeneutic reconstructive analysis in detail as follows:

The basic process involved in human understanding is hermeneutic, and hermeneutic processes involve a movement from initial holistic modes of understanding toward more explicit and delineated modes of understanding, which, in turn, modify one's holistic grasp of meaning. A circular process is involved: movement from the tacit (intuitive and undifferentiated) toward the explicit (delineated and differentiated) and then back to the holistic. (p. 95)

Another way to conceptualize the circular process characteristic of the hermeneutic reconstructive analysis, or what Crotty (2003) calls "the hermeneutic circle," is to think of it as "understanding the whole through grasping its parts, and comprehending the meaning of parts through divining the whole" (p. 92).

Thus, I began the data analysis by reading through all the notes and reflections, noting possible underlying meanings (i.e., a holistic understanding). Several such readings would begin to suggest patterns or themes that might be important to the analysis. Then selections of notes and reflections representative of the patterns or themes were analyzed for explicit meaning reconstructions (i.e., an explicit understanding of parts). The analysis of the selected notes and reflections, in turn, was used to confirm or modify the initial understanding grasped holistically. This circular whole-part-whole process was repeated until the holistic understanding of all the notes and reflections was aligned with the understanding derived from the explicit reconstructive analysis of parts of the notes and reflections. As a result of the hermeneutic reconstructive analysis, eight themes emerged from the data:

- having a better understanding of students

- forming a bond through writing notes 
- using multiple forms of literacy

- motivating reluctant writers to write

- wanting to write more

- learning to write through writing

- learning from students

- planning to take up dialogical writing in their own classrooms

In what follows, I will discuss and give examples of each theme. The discussion is intended to answer the first research question: what did the pre-service teachers know about their students through the dialogical notes?

\section{Having a Better Understanding of Students}

Through note writing, many pre-service teachers said that they understood their students better. Some of the pre-service teachers found out their students' favorite colors, food, sports, games, animals, and so on. For example, one pre-service teacher said in her reflection that her student, Maraya (pseudonyms are used for pre-service teachers and their students throughout this article), wrote about basketball in all of her notes:

By writing to Maraya I found out I was able to learn more about her life than our brief talks. I found that her major discourse was about basketball. Basketball in her family is a big deal and especially for her. In all of my notes to her they involved basketball. I later came to the conclusion that she felt that basketball makes people famous and she would love to be famous. (Kathy)

In addition, many elementary students opened up and were willing to share with the preservice teachers the information about their families such as their parents, grandparents, and other people with whom they lived. Here is a note from a third grader, Adam, talking about his family, "I have two brothers two bogs [dogs] I live with my dad." Similarly, another third grader wrote about his family:

I have a baby brother his name is Solomon he laughs sometime's my sister is 6 years old, My brother step is 3 years old. And CJ is 5 years old. How old are you? bo you like lemones?" (Eric)

One of the pre-service teachers learned to focus his notes on what the elementary student was interested in and kept the writing going. In their notes below, they talked about the movie character "Batman" and video games the kindergartener, Chris, brought up in his note. Chris wrote, "aer [Are] you Batman. on easter I playd lazer tag wit [with] my brazer [brother]. and I playd super Mario wold for super NiNtendow." In response, the pre-service teacher wrote: 
Dear Chris,

I'm not Batman. I'm sorry to hear you had a cold during Easter. I had a good Easter with my family. I play some video games, too, and some games at the table, too. I ate A LOT of food. I had some good pie. I love pie. I think I'm going to bring in some Batman dice soon to help us make a book. Does that sound cool?

Sincerely,

Mr. Ford

Lane (1993) argues that we need to discover that writing is not something a teacher tells us to do, but something real and as much a part of us as anything we have ever said and done. Lane's insight about writing is echoed by the examples presented above where the elementary students talked about what they liked/did, who they were, and things that happened in their daily lives. In this sense, writing dialogical notes is parallel to what Carspecken $(1999,2003)$ refers to as a communicative action orientated toward understanding others and being understood. The dialogical notes serve as a medium for the writers to understand, and to be understood by, each other. Through this mutual understanding, the teachers learn to better teach their students while the students learn to write better. Both parties are motivated to write because writing is not an end, but a means to recognize, and to be recognized by, the other party. For example, when the elementary students were willing to talk about themselves, their families, and their interests in their notes, they no longer regarded writing as a meaningless assignment, but as a communicative action to express themselves and to be recognized as unique individuals. In this way, the dialogical notes help teachers and students open up or "get naked" (Orfanella, 1996, p. 53) and allow the teachers to glean information about their students to inform their teaching.

\section{Forming a Bond through Writing Notes}

A total of eight pre-service teachers wrote in their reflections that they formed a bond with their students through writing the notes. In his reflection, one pre-service teacher stated:

I was floored at how enjoyable I found this writing project to be. I really feel like I formed a great bond with my child, Chris, I wouldn't have otherwise. Surprisingly, it wasn't a bond formed by the content of put notes, but rather the fact we had our own secret connection just between the two of us. Being in a multi child family and in a classroom of 25, Chris probably doesn't get as much 1 on 1 attention as he would like, and I believe this project helped fill that void. (Ford)

Similarly, another pre-service teacher, Laurie, said in her reflection, "I feel like this assignment allowed for me and the child to form a bond and we have a better understanding of each other." The relationships the pre-service teachers formed with their writing partners were so close that one of the elementary students even said in her note, "You are like a Mom to me. I love you! I do not want to stop loveing you" (Natilea). Another first grader, Katie, also expressed a similar feeling in her note, "I love Miss Judy so bad that she loves me and Just like my Mom." In parallel, Eric, a third grader, regarded his pre-service teacher as a role model and wanted to go to the same university as his pre-service teacher did. Eric wrote, "I have something to tell you I really want to be in the [name of the university] but I have to wait How long will it take me?"

The examples above show that, through note writing, the pre-service teachers and their students knew each other better and formed a bond that went beyond the traditional relationship 
between a teacher and a student. It was a kind of friendship that helped them connect to each other. This reformulated relationship allows students to communicate authentically in writing and is conducive to the teaching and learning of writing. It is in contrast to the traditional mode of writing instruction where the teacher plays the role of an authority, "policing student papers for mistakes" (Ballenger, 2013, p. 74).

\section{Using Multiple Forms of Literacy}

Although the elementary students were encouraged to complete the notes in writing, they were allowed to use alternative forms of literacy such as drawings. Therefore, some students chose to draw pictures in their notes and explained their pictures to the pre-service teachers. Some students began with drawing pictures and then added writing. Some students both wrote and drew pictures in their notes. A second grader even chose to verbally communicate some of his thoughts to his pre-service teacher, Petty, instead of writing notes. In her reflection, Petty noted, “... he often would verbally tell me his response to my dialogical notes rather than write it down. He bragged to me how well he could write but would never take the time to put his words on paper."

The pre-service teachers allowed their students to use alternative forms of literacy such as drawing and verbally communicating in addition to writing because they had read about the importance of embracing multiple forms of literacy (Lee, 2011) as well as multiple ways of knowing (Leland, Harste, \& Helt, 2000) in my class. These two articles argue that literacy should be regarded as multiple social practices rather than academic skills such as reading and writing only and that schools should allow students to demonstrate their understanding through multiple ways of knowing such as art, music, drama, movements, and so forth. Allowing their students to express their ideas in more than one form of literacy, the pre-service teachers demonstrated their understanding of these two articles and put their understanding into practice. An example of how the concept of multiple forms of literacy was put into practice in note writing is given below from Petty's reflection:

This experience was meaningful because it really highlighted the notion of multiple literacies. Rather than writing, Dennis might have communicated with me better had there been a different medium he could have used. For example, when replying to my notes, he often reenacted his story. In his first response, he wrote down what his favorite movie was, but he reenacted some of his favorite scenes.

\section{Motivating Reluctant Writers to Write}

Eight pre-service teachers reported in their reflections that they were assigned by their classroom teachers to work with students who did not like, or were not capable of, writing. Among the eight students, three were special needs students. Yet these so-called "reluctant" or "at-risk" writers turned out to enjoy writing notes with their pre-service teachers. For example, Kaily's classroom teacher did not believe that she liked writing. Yet Lora, the pre-service teacher with whom Kaily wrote, reported in her reflection how Kaily "blossomed into a writer after she was allowed to "write badly" (Ballenger, 2013). Specifically, after Kaily was told that she did not have to worry about her spelling, but focused on ideas, she began to open up and wrote about her family in the notes. Below is an excerpt of Lora's reflection about her writing experience with Kaily:

Throughout this semester, I was corresponding with a third-grade girl named Kaily. She is nine years old and African American. She attends the bilingual school of Linden 
Elementary [a pseudonym]. As I began writing with Kaily, I had prior knowledge that she was not very good at spelling, so it was the teacher's belief that she did not like to write. In our notes, Kaily shared with me that she loves reading and writing, and she seemed to light up when writing about her family and activities that she likes to write. One thing that piqued my interest almost immediately was that Kaily did not seem sure of her wording, as though she was afraid I would judge her poorly if she said something in an incorrect way or without formal English. I tried to incorporate the idea of "writing badly" like we had discussed in class, allowing her to talk about comforting subjects: her family, her dog, her favorite games and activities, etc. I was thrilled to see that she began using more of her home language in her responses. She slowly began to open up, talking about her experiences and adventures with her step-brother and sister, and telling me more about her own interests, although she was still fairly vague. I am curious as to how her writing would continue to develop if she began corresponding freely in a journal with her teacher or with a pen pal outside of school.

Likewise, Christy, another pre-service teacher working with David, a special needs student, told him not to worry about his spelling. This motivated David to write more than he would have done otherwise. Christy reflected on her writing experience as follows:

This was a different and wonderful experience. I witnessed how a child enjoys way more writing about things they are passionate about. At first David would ask me if he was spelling the words correctly. I had to let him know how I wasn't grading his spelling and I just wanted him to have freedom with this. I made sure he felt unjudged.

In parallel with Christy's comment about David, David's reflection about note writing was positive as well, "I liked writing back and forth. I dont like writing letters but this was fun becuse I got to writ my favorite thing's to do."

One common motivator present among these "reluctant" writers was that they were trusted as writers and told not to worry about grammar/spelling, but to focus on what they knew, were interested in, or were capable of. This is a paradigm shift from the traditional deficit-based instruction where we identify what students "cannot" do and try to remedy it. In deficit-based instruction, students are positioned as "receivers (and victims) of knowledge, not creators" (Campano, 2008, p. 145). Instead, the pre-service teachers focused on what their students could do and encouraged them to write about it. Once the students believed themselves as writers and were assured that people were interested in their writing, they began to tell their stories through writing.

\section{Wanting to Write More}

For this assignment, the pre-service teachers and their students each were asked to complete only five notes and one reflection. However, many of them said in their reflections that they enjoyed writing the notes so much that they wrote more than what they were required to do. For example, one pre-service teacher wrote in her reflection:

Even though we had finished our five entries to each other she had asked if we could still write to each other until I leave. I of course said yes and was very pleased to hear that she wanted to continue writing. (Judy) 
Similarly, another pre-service said in her reflection that her student could hardly wait to read her notes and write back to her.

Every Wednesday when I would walk into her classroom and set down my things, she would immediately run over to me and give me a hug and grab our journal. She could not wait to read what I wrote and to write back. (Alexis)

Because the pre-service teacher worked one-on-one with his/her elementary student during the practicum, this meant that only one student in a classroom had the opportunity to write notes with the pre-service teacher. Two pre-service teachers said in their reflections that other students in the classrooms who did not get a chance to write with them considered writing notes a "privilege" rather than a boring assignment. Ford, one of the pre-service teachers, noted, "One thing I found interesting was how jealous some of the other children got, and how much Chris seemed to bask in that jealousy, sometimes referring to our letters as 'top secret awesome notes' to other children." Erin also talked about how other students wanted to write with her:

From this assignment, I also learned that children love to write to me not just Allen. Every time I would write him back, a new student would come up to me and ask if they could be my pen pal too. I thought this was the greatest thing so I gave journals to the other students too so that they could write me. This way they could feel inspired to write without being prompted of what to say. With the students interested in writing, I want them to continue to write to each other after I am gone as long as it is outside of school to influence more writing and friendship.

The elementary students' enjoyment of writing notes brought up in the pre-service teachers' reflections above was a result of writing acquired as a social practice in a safe environment. Specifically, writing as a social practice is meant to understand and form a relationship with people, but not to be judged by what and how we write. Writing should be an avenue through which we can explore ourselves as well as the world around us. In this sense, writing is an act of risk taking. In fact, Orfanella (1996) compares sharing writing in English class metaphorically to showering together after gym class. He argues that asking students to share their writing is like sharing "their feelings and vulnerabilities, and their innermost thoughts" (Orfanella, 1996, p. 53). This is especially true when the power relationship between teachers and students is not equalized, but usually tilted in favor of the former. Because teachers are given power to grade students' work, students tend to write to please their teachers in order to receive good grades. Therefore, teaching writing is not simply teaching neutral knowledge of using words, grammar, and literary techniques, but creating a learning environment where students feel safe to take risks.

\section{Learning to Write through Writing}

Though writing notes with students did not involve formal instruction of writing as in a traditional classroom, several pre-service teachers reported that their students learned to write better through writing notes with them. Their students learned to improve writing in different ways. For example, one of the pre-service teachers, Breanna, wrote in her reflection: 
She [the elementary student] did not respond to me very much and only gave responses to my questions. The more we wrote, the more she wrote. At the beginning, she did not use an introduction or sign the notes, but as I kept doing it, she eventually started doing it. It wasn't something I made her do. She did it on her own.

Breanna's student was able to learn how to write not through formal writing instruction, but by looking at Breanna's notes as examples and imitating what she did. Actually, Breanna was not alone in seeing her student improve writing through writing with her. Another pre-service teacher, Judy, reported a similar experience in her reflection:

When I wrote my first note to her I wanted to not only know more about her but also what she knows when it comes to writing letters. After her first letter I realized that she had not included a Dear Miss Judy, date or closing. I wanted to wait and see if Katie would recognize what I was doing with my letter and follow that format also. With her being in first grade I was curious if she would recognize none of them, some or all. Katie's third writing ended with her saying, Your Friend Katie Smith. Even though she hadn't included the date and introduction I was so proud of her for noticing I closed my letter with a Your Friend, and that she should too. When I had told her how proud I was of her for doing that she had the biggest smile on her face and you could tell she was proud too.

Alexis also provided a detailed description in her reflection about the progress her student made in writing through this writing experience:

Natilea's writing ability benefited through this process. When we first started writing to each other I encouraged her to keep writing and to write more (her classroom teacher's request). Now at the end of this experience she writes two to three times as much with no prompting at all. She's proud of how much she can write. After writing her last note she proudly told me that she had written more than me. Also, the quality of Natilea's entries has also improved. At the beginning of our note writing she would answer the questions I asked in one sentence simple answers like "I like...." She has begun elaborating and going into more detail. She also writes now without hesitation. When we first started writing to each other she would come and ask me how to spell words multiple times while writing a note. Once she understood that this was not being graded on spelling and that ideas were all that mattered she quit asking and began writing freely.

The above examples are consistent with my finding reported in another study. Specifically, students are not "'taught,' but 'socialized' to the writing Discourse. This is because a Discourse, which consists of all the beliefs, values, actions, etc. socially accepted in a group, is acquired through socialization" (Lee \& Lee, 2015, p. 19). In school, writing is usually taught in a skill-based approach that focuses on parts (usually decontextualized parts) of writing such as spelling, vocabulary, grammar, etc. In contrast, writing through socialization is concerned with holistic ideas within sociocultural context as the pre-service teachers did with their students. 


\section{Learning from Students}

Just as the elementary students learned from the pre-service teachers, so did the pre-service teachers learn from their students. For example, Melinda learned to adapt her writing to align with her student's level:

At the beginning I overestimated Zoey's (a kindergartener) reading and writing skills. I wrote a long letter and asked several questions. When she did not respond to any of my questions in her letter, I had to change the way that I wrote mine. I learned how to adapt to her ability level and her preferred form of literacy. I could tell that she liked to draw pictures, so that is what I asked her to do. I noticed that she actually responded to my questions when I only asked one and asked her to draw a picture. She went into a lot more detail on some of her pictures than she really had to which I think shows that she was enjoying the experience and wanted to do a good job even though she was not getting a grade on it.

Unlike Melinda, Caitlyn was skeptical about her student's writing ability, but changed her misconception that "kindergarteners can't write."

I was very skeptical about this assignment at first because I was assigned in a kindergarten classroom but my views changed dramatically after writing with Natalie.... Natalie has opened my eyes and completely eliminated my thinking on "kindergarteners can't write" or "kindergarteners have trouble with their writing." I was completely blown away and infatuated when Natalie first wrote to me saying she wanted to be a dentist when growing up. I mean she is a 6-year-old and has the mind and passion of a high school student. When I was Natalie's age, my dream was being a princess or going to the moon or becoming a mermaid. I feel like we completely underestimate the minds of our youth. And not only would Natalie write to me, she would create a picture that connected to her story.

The examples above remind us as educators again not to impose on students a teachercentered curriculum, i.e., one based on our speculation about what our students can/cannot do or on our memory about how we were taught in the past. Instead, the curriculum should be created bottom-up based on what Lewison, Leland, and Harste (2008) refer to as students' personal and cultural resources such as "personal experience; social issues books; popular culture and media; home literacies; textbooks; oral texts; competence in a language other than English; student desires and interests; and community, national, and international issues" (pp. 5-7). Therefore, to teach students to write begins with an understanding of what they want to, and are able to, write about.

\section{Planning to Take up Dialogical Writing in Their Own Classrooms}

Having seen the benefits of writing with students, many pre-service teachers said that they would like to do it in their own classrooms in the future. For example, one of the pre-service teachers said, "I have grown from this experience as a pre-service teacher and hope to possibly incorporate this project in my own classroom someday." Similarly, Nicholas ended his reflection with, "This will be an activity that I plan on implementing in my own classroom." In addition to planning on doing this project in his own classroom, Ford hoped that his wife could do it to better connect with their son: 
Overall, I definitely plan on having my wife do this in the future with our son. I'm very close to him and I think this would be a fantastic way for her to connect a little better with him. I also think this would be a fantastic activity to do in my future classroom with all the kids individually as I could really get to know them and their home life better. I feel like this project taught me the value of one on one communication with children and how beneficial that can potentially be in forming a connection with my children in the classroom, and at the same time a fantastic literacy exercise.

This writing experience opened the pre-service teachers' eyes and even changed their concept about teaching writing. The pre-service teachers' endorsement of dialogical notes provided an answer to the central inquiry of this section - the first research question: what did the pre-service teachers know about their students through the dialogical notes? Through note writing, the pre-service teachers knew their students better (including their favorite sports, games, activities, family members...); formed a bond with their students; learned how to motivate their students to write by allowing them to use the forms of literacy they felt comfortable with; knew how to help reluctant writers to write by focusing on their strengths instead of weaknesses; witnessed that their students were able to learn to write through writing; and learned how to teach writing through writing with students. In addition, the pre-service teachers exhibited a strong interest in implementing dialogical notes in their future classrooms. Given all the things the preservice teachers learned about their students through the notes, were they able to put what they knew into practice? This question is actually what the second research question is concerned with and will be addressed in the following section.

\section{Teaching through Writing}

Now let us look at the second research question: how did the pre-service teachers use the information they learned from the dialogical notes to inform their teaching? In what follows, I will divide my response to this question into two parts: (a) learning to teach through writing dialogical notes and (b) building teaching on dialogical notes.

\section{Learning to Teach through Writing Dialogical Notes}

The discussion of learning to teaching through writing dialogical notes emphasizes what the pre-service teachers learned about teaching writing "during" the process of writing notes with their students. The dialogical notes were used not only as a tool for the pre-service teachers to know their students, but also as an avenue for them to teach writing in a way not typical of the writing instruction received in a traditional classroom. In other words, writing notes with students was actually a mutual learning process for the students and the pre-service teachers. The students learned to write from seeing what and how the pre-service teachers wrote in the notes. Likewise, the pre-service teachers learned to teach writing from being attentive to what and how their students wrote in the notes. Some pre-service teachers wrote about topics in which their students were interested to encourage more writing. Some motivated their students to write by telling them not to worry about spelling and grammar, but to focus on ideas. Some allowed their students to use multiple forms of literacy, such as writing, drawing, and speaking, to freely express their thoughts. Some adapted their writing to the level of their students to keep them engaged and interested in writing.

The analysis of the dialogical notes and reflections shows that the pre-service teachers learned to teach writing through the very act of writing with their students. This learning is 
different from the information they received from listening to lectures in class or the knowledge they gained from reading textbooks. Instead, the pre-service teachers analyzed their students' dialogical notes and used the information they learned from the notes to motivate their students to write. In this way, the pre-service teachers did not only write, but also improved their teaching of writing through writing with their students.

\section{Building Teaching on Dialogical Notes}

Another thing the pre-service teachers learned from the dialogical notes was related to their lesson planning. Specifically, the pre-service teachers were required to use the information they gleaned from the dialogical notes to create lesson plans. In what follows, I will present a lesson plan created by Jane based on her knowledge of the student through note writing. The presentation will focus on how the lesson plan relates to the dialogical notes instead of providing all the details about the lesson plan. In the excerpt of her lesson plan below, Jane discussed the connection between the lesson plan and her student:

Miranda is a little girl who just recently turned 9 . She is in the $3^{\text {rd }}$ grade, and she culturally identifies as white. Her school is comprised of a majority white population. She lives within the city limits of South Whitley, Indiana. There, she lives in an apartment complex with her mother, her mother's boyfriend, and a roommate of the house. Her father is not a part of Miranda's life. She is diagnosed with bipolar disorder, which inhibits her from maintaining positive peer relationships. She has few friends, and does not handle stressful situations well. In any conflict, Miranda has to be the correct one, and she can never be wrong. She is quick to get angry with her peers, and her verbal language is often defensive or heavily toned with aggression. This is why most of the children in her class avoid her. However, she cares very much about what people think of her. She is often chosen last when the class is allowed to choose partners, which is reflected in her self-esteem. Bipolar disorder also causes her to have trouble staying interested in material. When there is a lack of interest in the material, Miranda struggles to pay attention and her motivation decreases. She is driven solely on intrinsic motivation. She does what she wants to do, and nothing more. This often causes her to fall behind, which is reflected in her writing. She worries that she is not a good writer, so making the assignment less formal would benefit her greatly. This was apparent in our dialogical notes. She responded to writing much better in an informal exercise. When given a prompt from an instructor, Miranda typically disengages, and does not complete the assignment. However, if she is interested in the material Miranda shows much enthusiasm. Miranda is very passionate about Shopkins [small, collectable toys, manufactured by Moose Toys, based on grocery store items, each of which has a face and unique name], which is why I chose them as the center of this lesson plan. By using a concept that she is enthusiastic about, I believe that it will help her engage in the assignment, as well as respond to a writing assignment which she would usually ignore. I also hope to use the issue of confrontation in the assignment to help Miranda work out some conflict resolution strategies, which would help her maintain more positive peer relationships.

The following activities were designed by Jane to tap into Miranda's interest in Shopkins and to help her understand and foster positive peer relationships: 
In pairs, I would give Miranda and her teacher chosen partner (so she is not chosen last) a pencil, paper, and two Shopkins. In this case the two Shopkins are a toaster and a shampoo. I would then ask Miranda a prompt question, "What is a conflict your two characters might have? (Example: How can Toaster and Shampoo get along better when Toaster doesn't think Shampoo is a good soap?) Why do you think toaster feels this way? How do you think this makes Shampoo feel? If you were them, how would you solve their problem? How could you get them to get along?" Working with her partner, Miranda and the other student would write out dialogue between the two characters. This dialogue would include four components:

1. What is the conflict they have?

2. What are the two perspectives of the conflict?

3 . How are they going to resolve this conflict?

4. What actions are they going to take to prevent any further conflict?

The writing does not have to be perfect, and there is no penalty for incorrect spelling or grammar. There is no minimum page requirement. I just need them to get their ideas on paper. Once Miranda and her partner are finished with their script, they will perform their dialogue of the two characters for the class. If they have the time, they are welcome to prepare a set for the script, but it is not required.

In this lesson plan, Jane had two main objectives to accomplish. She wanted to help Miranda improve her relationship with peers, on the one hand, and her writing skills, on the other hand. Jane learned from the notes that Miranda was more likely to write about things she was passionate about, e.g., Shopkins, and that she preferred to write in a less formal setting. Therefore, Jane cleverly designed a lesson plan geared toward these two objectives through the use of Shopkins. Jane's lesson plan is singled out for discussion because it was characteristic of the other lesson plans designed by the pre-service teachers in the sense that it was created bottom-up based on a student's interest and need. In other words, all the pre-service teachers were able to come up with lesson plans that were built on what they had learned about their students from the dialogical notes though their students' interests (e.g., Shopkins, Batman, basketball, etc.) might vary from person to person.

\section{Conclusion}

At the beginning of this article, I explained the importance of building teaching on students' prior knowledge. To explore how my class assignment, dialogical notes, could help access students' prior knowledge, I formulated two research questions: (a) what did the pre-service teachers know about their students through the dialogical notes? and (b) how did the pre-service teachers use the information they learned from the dialogical notes to inform their teaching? Then examples of dialogical notes and reflections written by the pre-service teachers and their students were given to address these two research questions. I showed that dialogical notes served as a viable way for the pre-service teachers to know their students and teach them accordingly.

It is important to note that I am not arguing that if we use dialogical notes, we will automatically become good teachers. Dialogical notes, indeed, help us better understand our students. They inform us of how our students feel, what they like or dislike, what they do, and with whom they associate in school and at home, etc. Through note writing, we also learn if our students 
are good writers or struggle with writing. Such information can be gleaned from the dialogical notes, but the information itself is not sufficient to make us good teachers. It is "how" we use the information that will help us improve our teaching. For example, after we know our students' interests from their notes, we can do nothing or try to incorporate what they are interested in into our curriculum to engage them. Likewise, when writing with struggling or reluctant writers, we can choose to focus on their mechanical mistakes or tell them that their ideas are more important than writing perfectly. Therefore, it is not only "what" we know about our students from the dialogical notes (which is tied to the first research question), but also "how" we use the information we have learned from the dialogical notes (which is tied to the second research question) that makes a difference in our teaching.

\section{Notes}

1. Dialogical notes are letters/journals written by pre-service teachers and their elementary students. The letters/journals do not have to be formal with a date, salutation, signatory, etc., but can be as informal as personal notes. The notes are dialogical in nature because they are written back and forth or dialogically between the pre-service teacher and his/her elementary student. The purpose of writing the notes is to help the pre-service teachers have a better understanding of their elementary students. More details about dialogical notes will be provided later in this article.

\section{References}

Ballenger, B. (2013). The importance of writing badly. In B. Dethier (Ed.), Genres and how to write them (pp. 73-74). Boulder, CO: University Press of Colorado.

Campano, G. (2008). Vignette: Learning to teach by teaching in the margins. In M. Lewison, C. Leland \& J. Harste (Eds.), Creating critical classrooms: $K-8$ reading and writing with an edge (pp. 143-146). New York, NY: Lawrence Erlbaum Associates.

Carspecken, P. F. (1996). Critical ethnography in educational research: A theoretical and practical guide. New York, NY: Routledge.

Carspecken, P. F. (1999). Four scenes for posing the question of meaning and other essays in critical philosophy and critical methodology. New York, NY: Peter Lang.

Carspecken, P. F. (2003). Ocularcentrism, phonocentrism, and the counter enlightenment problematic: Clarifying contested terrain in our schools of education. Teachers College Record, 105(6), 978-1047.

Conley, M. W. (2008). Content area literacy: Learners in context. Boston, MA: Allyn and Bacon.

Crotty, M. (2003). The foundations of social research: Meaning and perspective in the research process. Thousand Oaks, CA: Sage Publications.

Dewey, J. (2013). My pedagogical creed. In D. J. Flinders \& S. J. Thornton (Eds.), The curriculum studies reader (4 ${ }^{\text {th }}$ ed.) (pp. 33-40). New York, NY: Routledge.

Gee, J. P. (1990). Social linguistics and literacies: Ideology in discourses. Bristol, PA: The Falmer Press.

Harste, J. (2008). Thought piece: Uncertainty and the teaching of reading and writing. In M. Lewison, C. Leland \& J. Harste (Eds.), Creating critical classrooms: $K-8$ reading and writing with an edge (pp. 35-37). New York, NY: Lawrence Erlbaum Associates.

Heath, S. B. (1983). Ways with words: Language, life, and work in communities and classrooms. Cambridge, UK: Cambridge University Press. 
Kidzworld (2014). All about the St. Patrick's Day leprechaun. Retrieved December 27, 2015 from http://www.kidzworld.com/article/7682-all-about-the-st-patricks-day-leprechaun.

Lee, C. J. (2011). What do we mean by literacy? Implications for literacy education. Journal of Educational Thought, 45(3), 255-266.

Lee, C. J., \& Lee, P. (2015). Socialization to writing: When writing is not "school-like." Talking Points, 27(1), 13-20.

Leland, C., Harste, J., \& Helt, C. (2000). Multiple ways of knowing: Lessons from a blue guitar. In M. A. Gallego \& S. Hollingsworth (Eds.), What counts as literacy: Challenging the school standard (pp. 106-117). New York, NY: Teachers College Press.

Lewison, M., Leland, C., \& Harste, J. (2008). Creating critical classrooms: K-8 reading and writing with an edge. New York, NY: Lawrence Erlbaum Associates.

Moll, L. (1992a). Bilingual classroom studies and community analysis: Some recent trends. Educational Researcher, 21(2), 20-24.

Moll, L. (1992b). Funds of knowledge for teaching: Using a qualitative approach to connect homes and classrooms. Theory into Practice, 31(2), 132-141.

Orfanella, L. (1996). Get naked. Teacher Magazine, 7(4), 53.

Street, B. (1984). Literacy in theory and practice. Cambridge, UK: Cambridge University Press.

Street, B. (1993). Cross-cultural approaches to literacy. New York, NY: Cambridge University Press.

Street, B. (1995). Social literacies: Critical approaches to literacy development, ethnography, and education. New York, NY: Longman. 